\title{
Inhibitory Effect of the Methanolic Extract of Verbascum latisepalum Hub.-Mor. on Endothelium-Dependent Relaxation in Rat Thoracic Aorta
}

\author{
T. Emrah Bozkurt ${ }^{\mathrm{a}, *}$, I. Irem Tatli ${ }^{\mathrm{b}}$, Cigdem Kahraman $^{\mathrm{c}}$, Zeliha S. Akdemir $^{\mathrm{c}}$, and \\ Inci Sahin-Erdemli ${ }^{\mathrm{a}}$ \\ a Department of Pharmacology, Faculty of Pharmacy, Hacettepe University, Sihhiye 06100, \\ Ankara, Turkey. Fax: +90 312 3114777. E-mail: turgutb@ hacettepe.edu.tr \\ b Department of Pharmaceutical Botany, Faculty of Pharmacy, Hacettepe University, Sihhiye \\ 06100, Ankara, Turkey \\ c Department of Pharmacognosy, Faculty of Pharmacy, Hacettepe University, Sihhiye 06100, \\ Ankara, Turkey \\ * Author for correspondence and reprint requests \\ Z. Naturforsch. 69c, 219-225 (2014) / DOI: 10.5560/ZNC.2013-0061 \\ Received March 28, 2013 / March 19, 2014 / published online June 5, 2014
}

\begin{abstract}
The leaves and flowers of Verbascum species are used to treat respiratory disorders, haemorrhoids, rheumatic pain, and wounds as well as for the treatment of eczema and other types of inflammatory skin conditions in traditional Turkish medicine. We examined the effect of the methanolic extract of the aerial parts of Verbascum latisepalum Hub.-Mor. on the endothelium-dependent relaxation response in rat aortic rings which is mediated by nitric oxide (NO). Six fractions, A-F, were obtained from the methanolic extract through bioassay-guided fractionation procedures. The phenylethanoid glycoside verbascoside was isolated from fraction D and its structure elucidated by spectral techniques. The inhibitory effects of the extract, its fractions, and verbascoside on the acetylcholineinduced relaxation response in phenylephrine-precontracted aorta was examined in the absence and presence of L-arginine, a precursor in the synthesis of NO. The observation that the effects of the methanolic extract, of fraction $\mathrm{D}$, and of verbascoside were reversed by L-arginine, indicates that verbascoside has an inhibitory effect on the synthesis of NO. This effect should be taken into consideration in view of the wide range of uses of Verbascum species in Turkish folk medicine.
\end{abstract}

Key words: Verbascum latisepalum, Nitric Oxide Synthase, Vasorelaxation

\section{Introduction}

A number of species of the Scrophulariaceae are valued for their curative properties and are widely used both in domestic and regular medicine. These plants are known as "sı̆̆ır kuyruğu" in Anatolia (Baytop, 1999). The genus Verbascum is represented by 233 species, 196 of which are endemic in the Turkish flora (Huber-Morath, 1978; Ekim, 2000). The leaves and flowers of Verbascum species are reported to have expectorant, mucolytic, and demulcent properties, and are used to treat respiratory disorders such as bronchitis, dry coughs, tuberculosis, and asthma in traditional Turkish medicine. The species are also used to treat haemorrhoids, rheumatic pain, superficial fungal infections, wounds, and several types of inflamma- tory skin diseases (Baytop, 1999; Turker and Camper, 2002; Turker and Gurel, 2005).

In our previous studies, antinociceptive and antiinflammatory activities of eight endemic Verbascum species were investigated. The methanolic extracts of these species displayed significant antinociceptive activity in the $p$-benzoquinone-induced writhing test, and anti-inflammatory activity at $200 \mathrm{mg} / \mathrm{kg}$ body weight per os using carrageenan-induced and $\mathrm{PGE}_{1}$-induced hind paw edema models and 12-O-tetradecanoyl-13acetate (TPA)-induced mouse ear edema models (Tatli et al., 2008; Akdemir et al., 2011). Besides these, the methanolic extracts of thirteen Verbascum species growing in Turkey, including $V$. latisepalum Hub.Mor., were also assessed for their in vivo woundhealing activity evaluated by linear incision and cir- 
cular excision experimental models and subsequent histopathological analysis. The methanolic extract of $V$. latisepalum was found generally highly effective (Süntar et al., 2010).

Phytochemical studies of these species have revealed the presence of phenylethanoid glycosides. Especially verbascoside is widely found in the genus Verbascum (Tatli and Akdemir, 2004). Phenylethanoid glycosides possess a number of biological activities such as antioxidant, anti-inflammatory, cytotoxic, antitumour, antiulcer, analgesic, antihypertensive, and immunosuppressive (Jimenez and Riguera, 1994). In addition, the nitric oxide (NO)-scavenging activity of phenylethanoids (verbascoside), which possibly contributes to their anti-inflammatory effects, has been demonstrated in lipopolysaccharide-stimulated murine macrophage cells (Xiong et al., 2000).

NO is a highly reactive free radical which is involved in the regulation of many physiological and pathophysiological processes (Hallinan et al., 2002; Ji et al., 2009). It is synthesized from L-arginine by three different isoforms of the enzyme nitric oxide synthase (NOS). The endothelial (eNOS) and neuronal (nNOS) isozymes are constitutive, while the third isoform is inducible NOS (iNOS) and is expressed in response to pro-inflammatory stimuli such as cytokines or pathogens (Garcin et al., 2008).

One of the important effects of NO is its vasorelaxant activity which is very critical in the regulation of vascular tone. In the vascular system it is synthesized in the endothelium and diffuses to the vascular smooth muscle inducing a relaxation response via a guanylate cyclase and cGMP-dependent pathway (Mayer and Hemmens, 1997). Therefore, blocking its effect may cause an increase in the vascular tone which leads to an elevation in blood pressure. This effect can be more significant in hypertensive condition. Considering the common systemic use of Verbascum species in traditional Turkish medicine, their vascular effects need to be determined. Here we investigated the effect of the methanolic extract of the aerial parts of $V$. latisepalum on the endothelium-dependent relaxation response in isolated rat thoracic aortae, and isolated and chemically characterized its active constituents through bioassay-guided fractionation procedures.

\section{Material and Methods}

\section{Plant material}

V. latisepalum Hub.-Mor. (Scrophulariaceae) was collected in a Pinus brutia forest between Burdur and
Cavdir in the Mediterranean region of Turkey during August 2002. Voucher specimens were authenticated by Prof. Hayri Duman, Gazi University, Faculty of Science, Etiler, Ankara, Turkey, and were deposited at the herbarium of the Faculty of Pharmacy, Hacettepe University, Ankara, Turkey (HUEF 02007).

\section{Bioassay-guided fractionation and isolation of active ingredients}

Preparation and fractionation of the $\mathrm{MeOH}$ extract

The air-dried and powdered aerial parts of $V$. latisepalum (327.3 g) were extracted twice with $\mathrm{MeOH}$ $(2 \times 2000 \mathrm{ml})$ at $40{ }^{\circ} \mathrm{C}$ for $12 \mathrm{~h}$. After evaporation of the solvent of the combined extracts in vacuo, $34.9 \mathrm{~g}$ $\mathrm{MeOH}$ extract were obtained. The methanolic extract was fractionated by vacuum liquid chromatography (VLC) over a polyamide column $(50-160 \mu \mathrm{m}, 250 \mathrm{~g}$; Fluka, Buchs, Switzerland), eluting with $\mathrm{H}_{2} \mathrm{O}$, followed by increasing concentrations of $\mathrm{MeOH}(0,25$, 50,75 , and $100 \%, 1600 \mathrm{ml}$ ) to afford six main fractions: fraction $\mathrm{A}, 4.50 \mathrm{~g}$; fraction $\mathrm{B}, 1.34 \mathrm{~g}$; fraction C, $2.52 \mathrm{~g}$; fraction $\mathrm{D}, 2.63 \mathrm{~g}$; fraction $\mathrm{E}, 383.0 \mathrm{mg}$; fraction F, $205.96 \mathrm{mg}$.

Chromatographic separation and isolation of the active constituents

Fraction D, which showed the highest activity for the inhibition of acetylcholine-induced relaxation response, was fractionated by VLC over a LiChroprep $\mathrm{C}_{18}$ column (C-18, Sepralyte $40 \mu \mathrm{m}, 150 \mathrm{~g}$; Merck, Opfikon-Glattbrugg, Switzerland). $\mathrm{A}_{2} \mathrm{O}$ and $\mathrm{MeOH}$ mixture $(30-100 \% \mathrm{MeOH})$ afforded seven subfractions: subfraction $\mathrm{D}_{1}, 46.5 \mathrm{mg}$; subfraction $\mathrm{D}_{2}$, $147.7 \mathrm{mg}$; subfraction $\mathrm{D}_{3}, 55 \mathrm{mg}$; subfraction $\mathrm{D}_{4}$, $43.1 \mathrm{mg}$; subfraction $\mathrm{D}_{5}, 66.2 \mathrm{mg}$; subfraction $\mathrm{D}_{6}$, $40.8 \mathrm{mg}$; subfraction $\mathrm{D}_{7}, 13.3 \mathrm{mg}$. The solvent polarity was changed by increasing the $\mathrm{MeOH}$ content. $\mathrm{Pu}-$ rification of subfraction $\mathrm{D}_{2}(147.7 \mathrm{mg})$ by silica gel (230 - 400 mesh, $140 \mathrm{~g}$; Merck) column chromatography $\left[\mathrm{CHCl}_{3} / \mathrm{MeOH}(70: 30 \rightarrow 60: 40)\right]$ furnished verbascoside $(85 \mathrm{mg})$, which was identified by $1 \mathrm{D}$ and 2D NMR and HR-ESI mass spectrometry as described previously (Akdemir et al., 2004).

\section{Biological activity tests}

Test animals

The study had been approved by Hacettepe University Animal Ethics Committee (No. 2008/29-7). Male 
Sprague-Dawley albino rats, weighing 200-250 g, were used in the study.

Drugs and solutions

Phenylephrine hydrochloride, acetylcholine hydrochloride, $N^{\omega}$-nitro-L-arginine methyl ester (LNAME) hydrochloride, and papaverine hydrochloride were purchased from Sigma-Aldrich (St. Louis, MO, USA). All drug solutions were prepared in distilled water. The methanolic extract of V. latisepalum was dissolved in dimethylsulfoxide (DMSO). DMSO at concentrations matching those in test solutions did not alter the acetylcholine-induced relaxation responses.

\section{Tissue preparation}

Rats were killed by exsanguination, and their thoracic aorta was isolated. Ring preparations of approximately $2-3 \mathrm{~mm}$ in length were prepared. Isometric changes in tension were recorded with an isometric force transducer (MAY95-transducer data acquisition system; COMMAT, Ankara, Turkey). The composition of the Krebs-Henseleit solution was (in $\mathrm{mM}$ ): $\mathrm{NaCl}$ (113), $\mathrm{KCl}$ (4.7), $\mathrm{MgSO}_{4}$ (1.2), $\mathrm{CaCl}_{2}$ (2.5), $\mathrm{KH}_{2} \mathrm{PO}_{4}$ (1.2), $\mathrm{NaHCO}_{3}$ (25.0), glucose (11.6); it was gassed with $95 \% \mathrm{O}_{2} / 5 \% \mathrm{CO}_{2}$ at $37{ }^{\circ} \mathrm{C}$ and $\mathrm{pH} 7.4$.

\section{Experimental protocol}

The aortic rings were mounted under a resting tension of $1.5 \mathrm{~g}$ in 10-ml organ baths filled with Krebs-Henseleit solution. Tissues were equilibrated for $1.5 \mathrm{~h}$ and washed with Krebs-Henseleit solution every $15 \mathrm{~min}$ before each experimental procedure.

The aortic rings were precontracted by $1 \mu \mathrm{M}$ phenylephrine $(60-80 \%$ of the maximum contraction), and then the relaxation response to acetylcholine $(10 \mathrm{nM}-0.1 \mathrm{mM})$ was evaluated by cumulative addition to the organ bath. The effects of the NOS inhibitor L-NAME $\left(10^{-5} \mathrm{M}\right)$, the methanolic extract of $V$. latisepalum, its fractions $\mathrm{A}-\mathrm{F}$, and verbascoside, which had been isolated from fraction $\mathrm{D}$, were examined on acetylcholine-induced relaxation responses. For this purpose, the tissues were incubated for $30 \mathrm{~min}$ with one of the substances mentioned above prior to precontraction with phenylephrine for the acetylcholine relaxation response. In another group of experiments, L-arginine $(1 \mathrm{mM})$ was added to the organ bath at the same time with either L-NAME, V. latisepalum extract, each of its fractions, or verbascoside to evaluate if it would affect the inhibition of the relaxation responses. Each concentrationresponse curve to acetylcholine was obtained with individual preparations.

The relaxation response to acetylcholine was expressed as the percentage of papaverine $\left(10^{-4} \mathrm{M}\right)$ induced relaxation. Papaverine was added to the organ bath after the maximum relaxation response to acetylcholine had been obtained.

\section{Statistical analysis}

Data are represented as means \pm standard error of the mean (S.E.M.). Statistical analysis was done by ANOVA/Newman-Keuls and Student's $t$-test using GraphPad Prism4 software. $P<0.05$ was considered as significant.

\section{Results and Discussion}

The effects of the methanolic extract of $V$. latisepalum on the acetylcholine-induced endotheliumdependent relaxation response in the rat thoracic aorta was examined. Rat thoracic aorta is a commonly used pharmacological preparation for determining the effect of test compounds on vascular relaxation (Pereira et al., 2013; Qian et al., 2012). Acetylcholine induces an endothelium-dependent relaxation response which is mediated by NO. NO plays an important role in the regulation of the vascular smooth muscle tone. It is mainly synthesized by eNOS in the endothelium and, after its release from endothelial cells, NO diffuses to the vascular smooth muscle cells and initiates vasodilation (Mayer and Hemmens, 1997). In the present study, a concentration-dependent relaxation response to acetylcholine $(0.1 \mathrm{nM}-0.1 \mathrm{mM})$ was obtained in isolated rat thoracic aorta (Fig. 1A). It is well established that this response is mainly mediated by NO in rat aorta (Palmer et al., 1987; Moncada and Higgs 2006; Loscalzo, 2013). Furthermore, in our study the acetylcholine-induced relaxation response was inhibited by the NOS inhibitor L-NAME $(10 \mu \mathrm{M})$, which is a pro-drug and releases the actual NOS inhibitor upon hydrolysis of the methyl ester (Fig. 1C). Increasing concentrations $(3-30 \mu \mathrm{g} / \mathrm{ml})$ of the methanolic extract of $V$. latisepalum inhibited the acetylcholine-induced relaxation response at 10 and $30 \mu \mathrm{g} / \mathrm{ml}$ (Fig. 1A). This inhibitory effect of the methanolic extract may occur through scavenging of $\mathrm{NO}$, attenuation of the synthesis of NO through inhibition of eNOS, through damage inflicted to the 
(A)

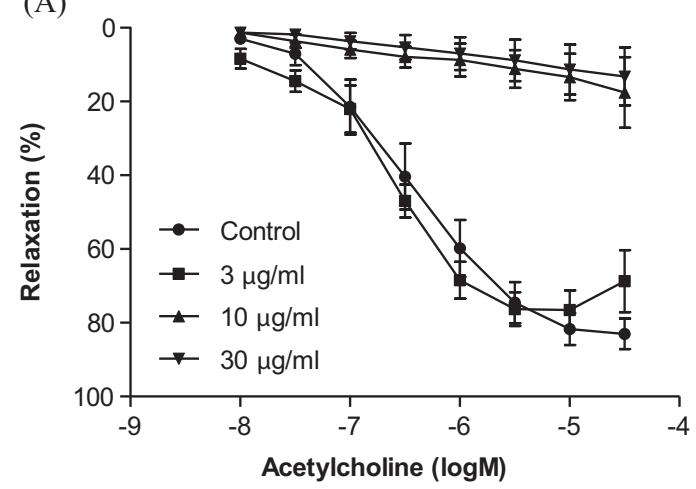

(B)

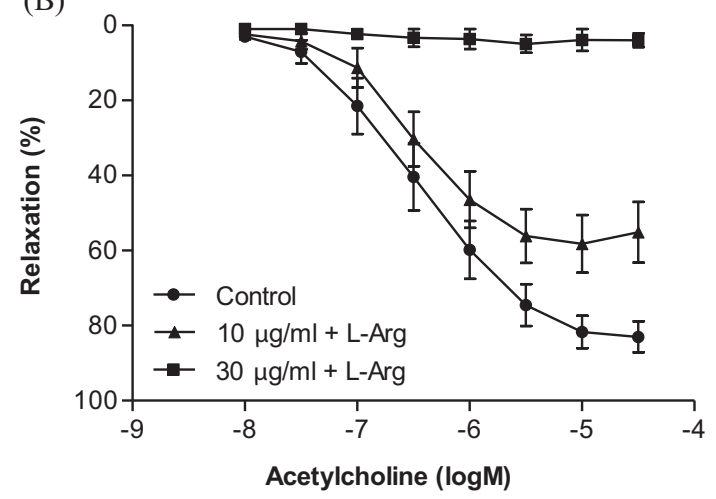

(C)

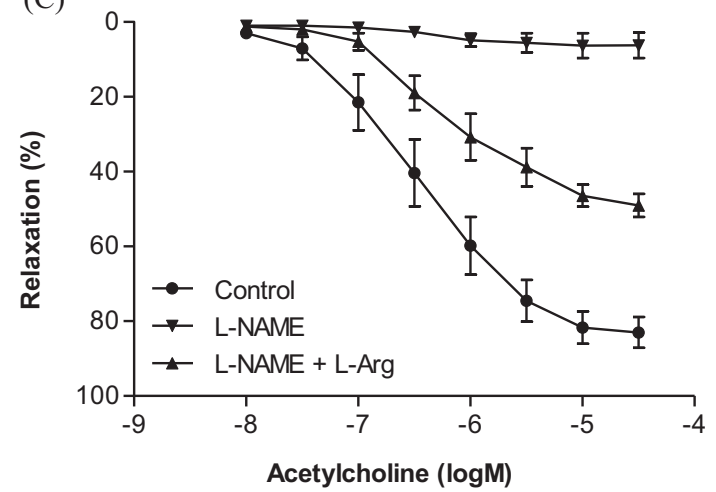

Fig. 1. (A) Concentration-dependent relaxation response to acetylcholine in the absence and presence of 3, 10, and $30 \mu \mathrm{g} / \mathrm{ml} \mathrm{V}$. latisepalum methanolic extract in isolated rat thoracic aorta. (B) Effect of $1 \mathrm{mM} \mathrm{L}$-arginine ( $\mathrm{L}-\mathrm{Arg}$ ) on the acetylcholine-induced relaxation response in the presence of 10 and $30 \mu \mathrm{g} / \mathrm{ml} \quad V$. latisepalum methanolic extract. (C) Effects of L-NAME $(10 \mu \mathrm{M})$ and L-NAME $(10 \mu \mathrm{M})+\mathrm{L}-\mathrm{Arg}(1 \mathrm{mM})$ on the acetylcholine-induced relaxation response in isolated rat thoracic aorta. endothelium, or interference with the signal transduction of NO. To identify the likely mechanism of this inhibition, we examined the effect of L-arginine which is the precursor of NO. The competitive nature of L-arginine's action against NOS inhibitors has been shown previously (Hecker et al., 1990; Cavalcante et al., 2010; Förstermann and Sessa, 2012). LArginine (1 mM) reversed the inhibitory effect of the $V$. latisepalum extract at $10 \mu \mathrm{g} / \mathrm{ml}$ but not at $30 \mu \mathrm{g} / \mathrm{ml}$ (Fig. 1B). This finding suggests that the inhibitory effect of V. latisepalum methanolic extract at $10 \mu \mathrm{g} / \mathrm{ml}$ concentration is mainly due to the inhibition of eNOS which is the main enzyme responsible for the synthesis of NO in the endothelium. To confirm this effect, a similar experiment was performed with the NOS inhibitor L-NAME. The inhibition of the response to acetylcholine by L-NAME $(10 \mu \mathrm{M})$ was also prevented in the presence of $\mathrm{L}$-arginine in isolated rat thoracic aorta (Fig. 1C). This finding supports our conclusion that the methanolic extract causes in vivo eNOS inhibition at $10 \mu \mathrm{g} / \mathrm{ml}$ concentration. On the other hand, the inhibitory effect at higher concentration of the extract $(30 \mu \mathrm{g} / \mathrm{ml})$ may be due to damage to the endothelium, since it was not reversed by L-arginine. This damage may be caused by saponins which are probably present in this extract. Saponins have been isolated from several Verbascum species growing in Turkey (Tatli and Akdemir, 2004), and are known to impair endothelial cell functions and abolish the endothelium-dependent relaxation response through endothelium denudation (Samata et al., 1986).

In the second part of the study, the effects of different fractions of the $V$. latisepalum methanolic extract were examined to identify the fraction responsible for the inhibitory effect on the acetylcholine-induced relaxation response. Six different fractions (by increasing polarity of the solvent) of the extract were obtained, and their effect on the relaxation response to acetylcholine was assessed. Inhibition of the response was obtained with fraction A at $10 \mu \mathrm{g} / \mathrm{ml}$, fraction B at 30 and $100 \mu \mathrm{g} / \mathrm{ml}$, fraction $\mathrm{C}$ at $10 \mu \mathrm{g} / \mathrm{ml}$, fraction $\mathrm{D}$ at 10 and $30 \mu \mathrm{g} / \mathrm{ml}$, fraction $\mathrm{E}$ at 30 and $100 \mu \mathrm{g} / \mathrm{ml}$, and fraction $\mathrm{F}$ at 30 and $100 \mu \mathrm{g} / \mathrm{ml}$ (Figs. $2 \mathrm{~A}-\mathrm{F}$ ).

Next, the effects of L-arginine on the inhibition brought about by these fractions were tested as described above. L-Arginine reversed the inhibitory effect of fraction D at $10 \mu \mathrm{g} / \mathrm{ml}$ but none of the effects of any other fraction, or of $30 \mu \mathrm{g} / \mathrm{ml}$ of fraction D (Figs. 2A-F). This finding indicates that only the action of $10 \mu \mathrm{g} / \mathrm{ml}$ of fraction D appears to be truly me- 
(A)

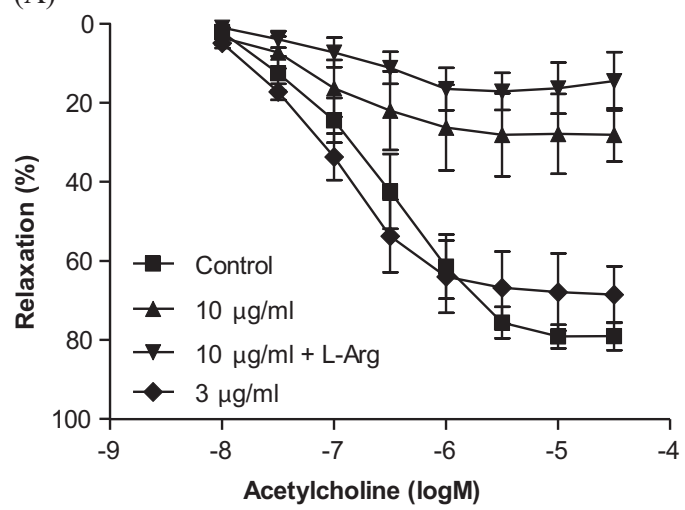

(B)

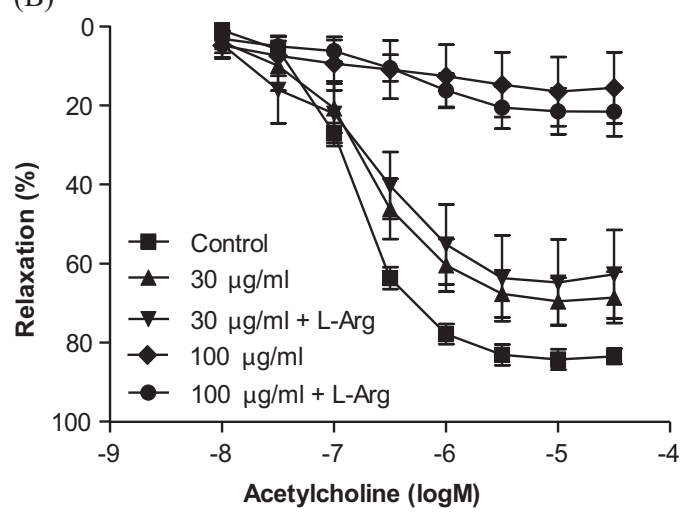

(C)

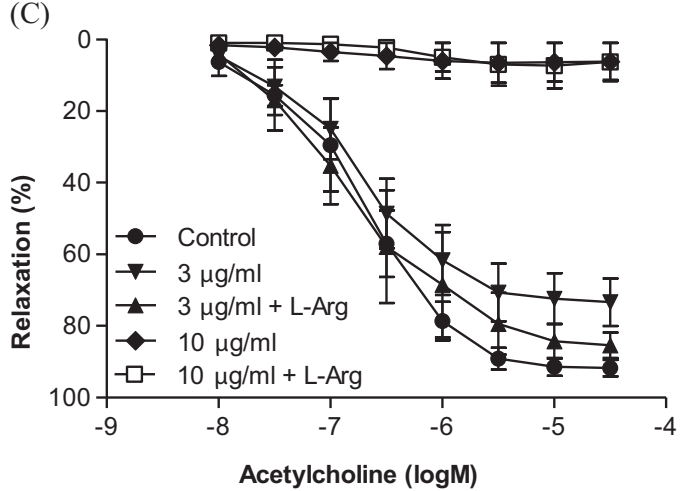

(D)

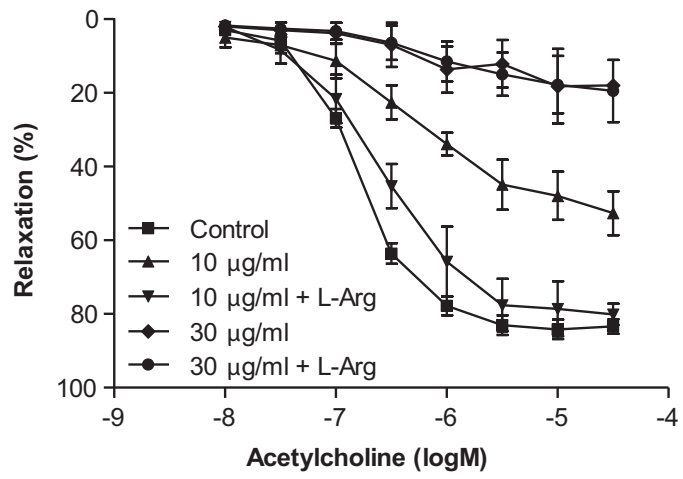

(E)

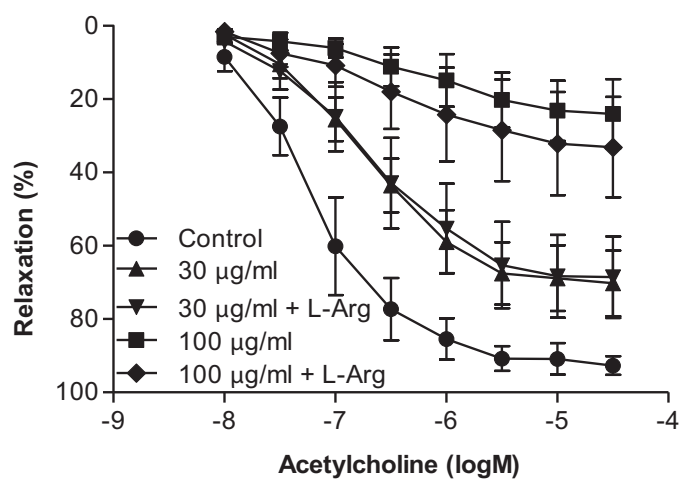

(F)

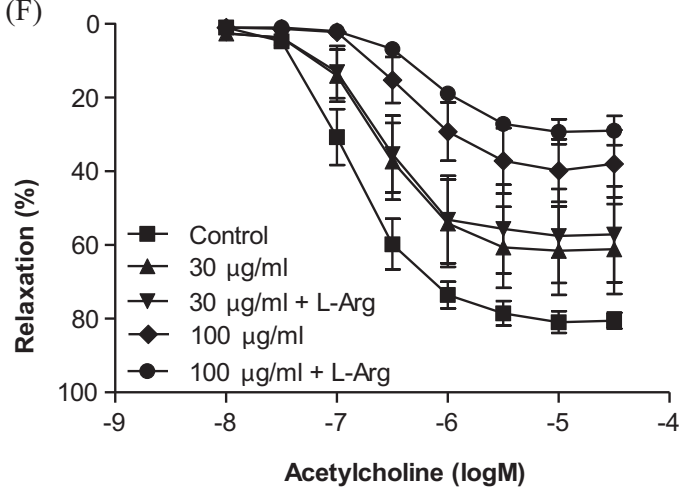

Fig. 2. Concentration-dependent relaxation response to acetylcholine in the absence and presence of different concentrations of (A) fraction A, (B) fraction $\mathrm{B},(\mathrm{C})$ fraction $\mathrm{C},(\mathrm{D})$ fraction $\mathrm{D},(\mathrm{E})$ fraction $\mathrm{E},(\mathrm{F})$ fraction $\mathrm{F}$, and the effect of $\mathrm{L}$-arginine (L-Arg) (1 mM) on these responses.

diated through inhibition of eNOS. The inhibitory effect of other fractions tested seems to be more likely mediated through saponin-induced endothelial damage rather than eNOS inhibition as suggested above for the high concentration $(30 \mu \mathrm{g} / \mathrm{ml})$ of the methanolic extract itself.

Fraction D contains the biologically active compound verbascoside. This compound inhibited the re- 


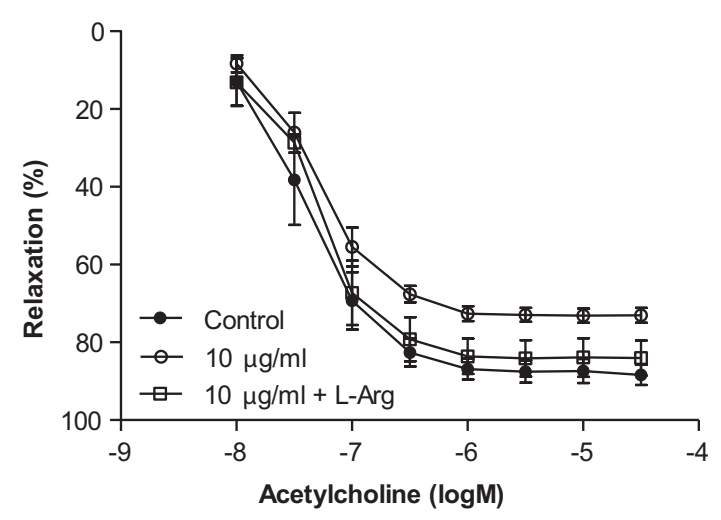

Fig. 3. Concentration-dependent relaxation response to acetylcholine in the absence and presence of $10 \mu \mathrm{g} / \mathrm{ml}$ verbascoside and $10 \mu \mathrm{g} / \mathrm{ml}$ verbascoside $+1 \mathrm{~mm} \mathrm{L-arginine}$ (L-Arg) in isolated rat thoracic aorta.

laxation response at $10 \mu \mathrm{g} / \mathrm{ml}$, and this inhibitory effect was attenuated in the presence of L-arginine (Fig. 3). This data again indicates that the inhibitory effect of verbascoside is due to the inhibition of eNOS, as suggested for the inhibitory effects of V. latisepalum methanolic extract and fraction D, both at $10 \mu \mathrm{g} / \mathrm{ml}$.

An activity of verbascoside leading to in vivo NOS inhibition parallels findings of other studies. It has been demonstrated that verbascoside enhances the vasoconstriction response through inhibition of en-

Akdemir Z.-S., Tatli I.-I., Bedir E., and Khan I.-A. (2004), Iridoid and phenylethanoid glycosides from Verbascum lasianthum. Turk. J. Chem. 28, 227 - 234.

Akdemir Z.-S., Kahraman C., Tatli I.-I., Akkol E.-K., Suntar I., and Keles H. (2011), Bioassay-guided isolation of anti-inflammatory, antinociceptive and wound healer glycosides from the flowers of Verbascum mucronatum Lam. J. Ethnopharmacol. 136, 436-443.

Baytop T. (1999), Therapy with Medicinal Plants in Turkey (Past and Present), 2nd ed. Nobel Tip Kitabevleri Ltd, Istanbul, Turkey, p. 134.

Cavalcante H.-M.-M., Ribeiro T.-P., Silva D.-F., Nunes X.P., Barbosa-Filho J.-M., Diniz M.-F.-F.-M., Correia N.A., Braga V.-A., and Medeiros I.-A. (2010), Cardiovascular effects elicited by milonine, a new 8,14dihydromorphinandienone alkaloid. Basic Clin. Pharmacol. Toxicol. 108, $122-130$.

Ekim T. (2000), In: Flora of Turkey and East Aegean Islands, Vol. 11 (Guner A., Ozhatay N., Ekim T., and Baser K.-H.-C., eds.). University Press, Edinburgh, UK, p. 193. dothelial NO formation (Tam et al., 2002). In another study, verbascoside was shown to impair aortic relaxation partially through inhibition of endothelial NO production (Lau et al., 2004). Besides inhibiting eNOS, verbascoside has also inhibitory activity on iNOS, which may be involved in the anti-inflammatory effect of V. latisepalum (Garcin et al., 2008).

In conclusion, the inhibitory effects of the methanolic extract of $V$. latisepalum, its fraction $\mathrm{D}$, and the biologically active compound verbascoside on acetylcholine-induced endothelium-dependent relaxation response seem to be mediated via the inhibition of eNOS. The finding that the NO precursor L-arginine attenuates this inhibition supports this hypothesis, because L-arginine also attenuates the effect of the NOS inhibitor L-NAME. However, there are possibly other substances in the extract that also counteract acetylcholine-induced responses. Because the methanolic extract, fraction $\mathrm{D}$, and verbascoside all exerted comparable inhibitory activities at $10 \mu \mathrm{g} / \mathrm{ml}$ concentration, it appears that verbascoside has a low specific activity, and that there are additional compounds in the extract and fraction D that contribute to the inhibitory effect of acetylcholine-induced relaxation responses. Since there is a wide range for the traditional use of Verbascum species, the eNOS inhibitory effect of this plant should always be taken into consideration for patients with hypertension and other vascular diseases.

Förstermann U. and Sessa W.-C. (2012), Nitric oxide synthases: regulation and function. Eur. Heart J. 33, 829-837.

Garcin E.-D., Arvai A.-S., Rosenfeld R.-J., Kroeger M.-D., Crane B.-R., Andersson G., Andrews G., Hamley P.-J., Mallinder P.-R., and Nicholls D.-J. (2008), Anchored plasticity opens doors for selective inhibitor design in nitric oxide synthase. Nat. Chem. Biol. 4, 700-707.

Hallinan E.-A., Tsymbalov S.-T., Dorn C.-R., Pitzele B.-S., Hansen D.-W., Moore W.-M., Jerome G.-M., Connor J.R., Branson L.-F., Widomski D.-L., Zhang Y., Currie M.G., and Manning P.-T. (2002), Synthesis and biological characterization of L-N(6)-(1-iminoethyl)lysine 5tetrazole-amide, a prodrug of a selective iNOS inhibitor. J. Med. Chem. 45, 1686-1689.

Hecker M., Sessa W.-C., Harris H.-J., Anggard E.-E., and Vane J. (1990), The metabolism of L-arginine and its significance for the biosynthesis of endothelium-derived relaxing factor: Cultured endothelial cells recycle Lcitrulline to L-arginine. Proc. Natl. Acad. Sci. USA 87, $8612-8616$ 
Huber-Morath A. (1978), In: Flora of Turkey and East Aegean Islands, Vol. 6 (Davis P.-H., ed.). University Press, Edinburgh, UK, p. 461.

Ji H.-T., Li H.-Y., Martasek P., Roman L.-J., Poulos T.-L., and Silverman R.-B. (2009), Discovery of highly potent and selective inhibitors of neuronal nitric oxide synthase by fragment hopping. J. Med. Chem. 52, 779- 797.

Jimenez C. and Riguera R. (1994), Phenylethanoid glycosides in plants: structure and biological activity. Nat. Prod. Rep. 11, 591-606.

Lau C.-W., Chen Z.-Y., Wong C.-M., Yao X., He Z., Xu H., and Huang Y. (2004), Attenuated endothelium-mediated relaxation by acteoside in rat aorta: Role of endothelial $\left[\mathrm{Ca}^{2+}\right]_{\mathrm{i}}$ and nitric oxide/cyclic GMP pathway. Life Sci. 75, $1149-1157$.

Loscalzo J. (2013), The identification of nitric oxide as endothelium-derived relaxing factor. Circ. Res. 113, $100-103$.

Mayer B. and Hemmens B. (1997), Biosynthesis and action of nitric oxide in mammalian cells. Trends Biochem. Sci. 22, $477-481$.

Moncada S. and Higgs E.-A. (2006), The discovery of nitric oxide and its role in vascular biology. Br. J. Pharmacol. 147, $193-201$.

Palmer R.-M., Ferrige A.-G., and Moncada S. (1987), Nitric oxide release accounts for the biological activity of endothelium-derived relaxing factor. Nature 327, $524-526$.

Pereira S.-L., Marques A.-M., Sudo R.-T., Coelho Kaplan M.-A., and Zapata-Sudo G. (2013), Vasodilator activity of the essential oil from aerial parts of Pectis brevipedunculata and its main constituent citral in rat aorta. Molecules 18, $3072-3085$.
Qian L.-B., Fu J.-Y., Cai X., and Xia M.-L. (2012), Betulinic acid inhibits superoxide anion-mediated impairment of endothelium-dependent relaxation in rat aortas. Indian J. Pharmacol. 44, 588-592.

Samata K., Kimura T., Satoh S., and Watanabe H. (1986), Chemical removal of the endothelium by saponin in the isolated dog femoral artery. Eur. J. Pharmacol. 128, $85-91$.

Süntar I., Tatlı I.-I., Küpeli Akkol E., Keleş H., Kahraman C., and Akdemir Z.-S. (2010), An ethnopharmacological study on Verbascum species: From conventional wound healing use to scientific verification. J. Ethnopharmacol. 132, 408-413.

Tam W.-Y., Chen Z.-Y., He Z.-D., Yao X., Lau C.-W., and Huang Y. (2002), Enhancement of contraction of rat mesenteric artery by acteoside: Role of endothelial nitric oxide. J. Nat. Prod. 65, 990-995.

Tatli I.-I. and Akdemir Z.-S. (2004), Chemical constituents of Verbascum L. species. J. Pharm. Sci. 29, 93-107.

Tatli I.-I., Kupeli Akkol E., Yesilada E., and Akdemir Z.-S. (2008), Antinociceptive and anti-inflammatory activities of seven endemic Verbascum species growing in Turkey. Pharm. Biol. 46, 781 - 788.

Turker A.-U. and Camper N.-D. (2002), Biological activity of common mullein, a medicinal plant. J. Ethnopharmacol. 82, $117-125$.

Turker A.-U. and Gurel E. (2005), Common mullein (Verbascum thapsus L.): Recent advances in research. Phytother. Res. 19, $733-739$.

Xiong Q., Tezuka Y., Kaneko T., Li H., Tran L.-Q., Hase K., Namba T., and Kadota S. (2000), Inhibition of nitric oxide by phenylethanoids in activated macrophages. Eur. J. Pharmacol. 400, 137 - 144 . 